\title{
Analysis of Prospective Turkish Language and Literature Teachers' Self-efficacy Perceptions on Critical Reading
}

\author{
Ayşe Derya Eskimen \\ Faculty of Education, Kütahya Dumlupinar University, Turkey
}

Copyright $\mathrm{C} 2018$ by authors, all rights reserved. Authors agree that this article remains permanently open access under the terms of the Creative Commons Attribution License 4.0 International License

\begin{abstract}
The purpose of this study is to determine self-efficacy perceptions of prospective Turkish language and literature teachers on critical reading with respect to a myriad of variables. On the basis of obtained findings, this study seeks to provide a conclusion and suggestions for future studies. Data relevant of this study were collected via administering "Critical Reading Self-efficacy Perception Scale" developed by Karadeniz [13]. In data analysis, descriptive statistics were employed; data collected via the scale were interpreted by using independent sampling $\mathrm{t}$ test and one-factor variance analysis (ANOVA). Gathered results were then tabulated. This research was conducted during the fall term of 2017-2018 academic year among 150 prospective teachers studying in Turkish Language and Literature Teaching Departments of two major city universities. It was concluded that self-efficacy perceptions of prospective teachers on critical reading varied insignificantly with respect to enrolled university, gender, grade level, age, education level of parents, family income level and frequency of reading books. Nonetheless it differed significantly with respect to annual ratio of book reading and availability of a library in their residential location.
\end{abstract}

Keywords Reading, Critical Reading, Self-efficacy, Prospective Turkish Language and Literature Teacher

\section{Introduction}

Concepts of criticism and critical thinking have recently gained widespread popularity. In the latest version of Turkish dictionary [10] criticism is defined such; "An act of investigation to the end of unveiling and demonstrating the rights and wrongs of a person; a work; a topic; it is a negative review". "In everyday language, it is evident that criticism mostly reflects a negative connotation. Criticizing something refers to showing its negative aspects, but in its real sense criticism aims not to oppose but to expose" [11]. Hence, criticism is not necessarily negation of the subject matter; it is a process of analyzing, deducing and questioning. In relation to that, critical viewpoint is a way of thinking that entails the entire process of evaluation, analysis, synthesis and deduction, questioning and relevant dimensions.

In social life critical thinking is one of the behaviors that must be adopted by all. Advancing technology and shifting social structure necessitate critical thinking and critical point of view. Indeed, upon gaining reading and writing skills people rapidly resort to information-access tools by using visual, printed, communicative and correspondence tools. The truth is, in modern age, the internet and television have turned into vital resources storing any type of needed information next to books and libraries. Nonetheless validity and reliability of the information in such sources may be doubtful. Accordingly, John Naisbitt's quote: "We are drowning in information but starved for knowledge" [21] signifies the threat of superficial knowledge spread via technology and consequential pollution of information; in another saying Naisbitt draws the attention on the abundance of superficial and fragmented pieces of knowledge of which accuracy is yet to be approved.

Unless particular care is paid, both printed and audio-visual media can trigger raising dogmatic citizens although the very same citizens can also gain critical thinking skills through these means. In that sense "there are five basic concepts and key questions that can be administered to media products" [8]. Indeed Kurt and Kürüm also argue that [16] in order to make a judgment, a person qualified with critical thinking skills operates his/her intellect to analyze the accuracy of information sources, and can identify supportive evidences, differences and similarities in favor of the claims. From that viewpoint it is feasible to argue that critical reading and thinking skill 
is essential to determine the accuracy of any given information.

\section{Reading, Critical Reading and Self-efficacy}

Being one of the preliminary language skills, reading is an intellectual activity that is related to a recipient's reaction to a text with the intention of solving the code of a written text, a graphically scripted statement and to interpret a written text; reading is a dynamic process of establishing meaning that necessitates active and effective communication between the writer and the reader; reading is the quickest road that can unite individuals with information [9]; [1]; [23].

As is the case for every business, reading \& writing also has a scientific ground. This science is required not only to comprehend and evaluate the knowledge and message conveyed by the text authors accurately but also essential to protect the readers from the sinister traps of information age, which could only be detected by a few masterminds. The type of ignorance and vulgarity defined as "Ignorance of information" is the kind of knowledge lack gained by excessive reading without any purpose and adopting excessive amounts of information... Any reader with no critical reading skill may fall into the trap of information ignorance the more $s /$ he reads [6]. That being the case "critical reading is thinking about a text to be read, brainstorming on the rights and wrongs and interpreting the subject matter; critical reading is testing and evaluating the read subject based on personal knowledge background; critical reading is an individual's justifying, questioning and analyzing what is read before reaching a conclusion by utilizing reliable sources and his/her intellect; it means activating a communicative interaction. To put this differently it refers to the acquisition of receptive skills of the message conveyed by the author" [24]; [22]; [26]; [25].

One of the key factors in effectuating critical reading is the person's self-efficacy perception/notion to the specific case. Notion of self-efficacy is one of the basic concepts of social-learning theory (social-cognitive theory) developed by Albert Bandura. Bandura asserts that [5] self-efficacy notion is; "A person's self-perception on his/her capacity to prosper by organizing required activities to achieve a certain level of performance". Senemoğlu claims that [27] self-efficacy is a person's faith on his/her capacity and talent to cope with different situations and a given activity, self-confidence and self-reflection. Self-efficacy notion is defined as the determinant of behaviors and behavior changes. Bandura's studies reveal that a person's perception of his/her skills not only affects behaviors but also his/her motivation and success [15]. Indeed the stronger a person's self-efficacy notion the stronger is the effort, persistence and motivation exerted in performing the task. "Relevant studies point out that individuals choose to perform the tasks they feel safe and proficient while they tend to avoid the tasks they feel like a failure; unless they trust in acquiring the results they want, they would be unwilling to take action; as a result a person's self-efficacy faith would be a determinant behind their personal choices [15]. Accordingly we hold the belief that prospective Turkish language and literature teachers who are qualified with critical reading proficiency and faith would exert stronger effort, persistence and perseverance to convey the same notion to their students when compared to other teachers.

\section{Turkish Language Literature and Critical Reading}

Critical reading is a set of activities related to an individual's pursuit of attaining the better, the more appealing and more accurate by filtering what is being read and learnt through reviewing from his/her personal knowledge and background; it is an act of demonstrating the better, the more appealing and more accurate intellectual products through the acquisitions from reading [6]. "In critical reading the reader should demand to be aware of what is written to what end and in which manner as well. The reader should pay heeds to the attitude adopted by the writer in conveying a given text, consistency of provided information and selected words. This ability calls for additional knowledge, skills and habits in addition to basic literacy skills" [2].

Literature is one domain that is essential for an entire life time. The objectives that literatüre teaching should instill on students should provide opportunities for critical and reflective thinking; creative writing and speech. As is expected in all other stages of learning, prospective Turkish language and literature teachers should set good role models in promoting reading habits among their students. As argued by Ahmet Hamdi Tanpinar [28], high-school teachers assume great responsibility because they are the ones forming a human being. Critical thinking, critical reading, critical listening skills are listed as course-specific skill objectives in the general and specific objectives of the latest Turkish Language and Literature Curriculum approved in 2018. Indeed in the course-specific objectives it has been underlined that "the program aims to gain reading habits to students by developing reading comprehension and critical reading skills via texts"[19]. As emphasized by Erden [7] "Success ratio of higher education students is heavily reliant on the quality of education in secondary education institutes. Accordingly it is a noteworthy change that in Turkish language and literature curriculum and course-books critical reading is now an integral component. It is also expected that in high schools Turkish language and literature teachers who would be role models in this pursuit should hold positive insights on critical reading and positive perceptions on their critical reading self-efficacy. Consequently, it is a matter of importance that during their undergraduate education teachers adopt a critical reading self-efficacy." In that sense in the Turkish language and literature teaching 
departments of universities, specific courses should be integrated to hone relevant skills. Indeed in the course-specific competencies of

Turkish language and literature teachers issued by the Ministry of National Education in 2011 [18], the item "Competent to improve the critical and creative thinking, decision-making and problemsolving skills of students" was integrated.

\section{Materials and Methods}

In this part research objective, background of the research, model, research population, data collection and analysis have been explained.

\subsection{Research Objective}

The objective of this study is to determine self-efficacy perception of prospective Turkish language and literature teachers on critical reading with respect to a myriad of variables. To that end below- given questions have been sought for answers:

1. What are the critical reading self-efficacy perception levels of prospective teachers?

2. Do critical reading self-efficacy perception levels of prospective teachers significantly vary with respect to variables viz. enrolled university, gender, grade level, age, education level of parents, family income level and frequency of reading books, annual ratios of book reading and availability of a library in their residential location?.

\subsection{Importance of Research}

In relevant literature a number of studies have focused on the critical reading self-efficacy perceptions of prospective teachers studying at departments of classroom teaching, social sciences teaching, Turkish teaching, computer and instructional technologies teaching, preschool teaching, psychological counseling and guidance teaching, science teaching, English teaching and physical education teaching [17], [14], [29], [4], [3], [20] etc. Nonetheless there has not yet any study been identified on analyzing reading and critical reading perceptions of prospective Turkish language and literature teachers expecting to graduate from a reading-based and text-based program such as literature and aspiring to be role models in instilling reading habit to their students. Thus we hold the belief that identification of prospective Turkish language and literature teachers' perceptions on reading and critical reading would offer a contribution to relevant literature.

\subsection{Research Model}

This study aiming to designate critical reading self-efficacy perception levels of prospective teachers enrolled in Turkish language and literature teaching departments of two different universities during 2017-2018 academic year was patterned in survey model.

\subsection{Participants}

Research population consists of 150 prospective teachers studying in Turkish Language and Literature Teaching Departments of two major city universities during the fall term of 2017-2018 academic year. Demographic features of participant prospective teachers are as seen in Table 1 .

Table 1. Demographic features of prospective teachers

\begin{tabular}{|c|c|c|c|}
\hline & & f & $\%$ \\
\hline \multirow{2}{*}{ University } & 1. University & 77 & 51,3 \\
\hline & 2. University & 73 & 48,6 \\
\hline \multirow{2}{*}{ Gender } & Female & 108 & 72 \\
\hline & Male & 42 & 28 \\
\hline \multirow{4}{*}{ Grade } & 1. grade & 43 & 28,6 \\
\hline & 2. grade & 37 & 24,6 \\
\hline & 3. grade & 32 & 21,3 \\
\hline & 4. grade & 38 & 25,3 \\
\hline \multirow{2}{*}{ Age } & $18-20$ & 92 & 61,3 \\
\hline & $21-23$ & 58 & 38,6 \\
\hline \multirow{4}{*}{$\begin{array}{c}\text { Education } \\
\text { level of } \\
\text { mother }\end{array}$} & Elementary education & 86 & 57,3 \\
\hline & Secondary education & 21 & 14 \\
\hline & High-school & 29 & 19,3 \\
\hline & University & 14 & 9,3 \\
\hline \multirow{4}{*}{$\begin{array}{c}\text { Education } \\
\text { level of father }\end{array}$} & Elementary education & 55 & 36,6 \\
\hline & Secondary education & 26 & 17,3 \\
\hline & High-school & 48 & 32 \\
\hline & University & 21 & 14 \\
\hline \multirow{3}{*}{$\begin{array}{c}\text { Family } \\
\text { income level }\end{array}$} & $1500-3000$ & 102 & 68 \\
\hline & $3000-4500$ & 40 & 26,6 \\
\hline & 4500 and above & 8 & 5,3 \\
\hline \multirow{3}{*}{$\begin{array}{l}\text { Frequency of } \\
\text { reading books }\end{array}$} & Everyday & 66 & 44 \\
\hline & Weekly & 49 & 32,6 \\
\hline & Once in a mont $\mathrm{h}$ or less & 35 & 23,3 \\
\hline \multirow{3}{*}{$\begin{array}{c}\text { Annual ratio } \\
\text { of book } \\
\text { reading }\end{array}$} & $1-5$ books & 14 & 9,3 \\
\hline & 6-20 books & 83 & 55,3 \\
\hline & 21 and above & 53 & 35,3 \\
\hline $\begin{array}{c}\text { Availability of } \\
\text { a library in }\end{array}$ & Yes & 135 & 90 \\
\hline $\begin{array}{c}\text { residential } \\
\text { location }\end{array}$ & No & 15 & 10 \\
\hline
\end{tabular}

Information in Table 1 shows that $51 \%$ and $48 \%$ ratios of participants are enrolled to two different universities. As seen female students $(72 \%)$ are dominant section. 1st grade students constitute the majority (29\%); students between the age range of $18-20$ are more in number $(61 \%)$; mothers 
(57\%) and fathers (37\%) are mostly elementary school graduates. Family income level varies between 1500 to 3000 TL (68\%); the ratio of those reading a book everyday $(44 \%)$ constitute a wider segment; annual frequency of reading books changes between 6 to 20 books $(55 \%)$ and there is $90 \%$ availability of library in their residential location.

\subsection{Data Collection and Analysis}

In order to determine critical reading self-efficacy perceptions of university students "Critical Reading Self-efficacy Perception Scale" developed by Karadeniz [13] was employed. It is a five-Likert type scale containing 33 items. In the scale 25 items are positive and 8 items are negative. Negative items were inversely scored. Within the context of research, to the end of identifying demographic features of prospective teachers, a personal-information form was attached to the measurement tool. Options in the scale were listed as "I completely disagree", "I disagree", "I am undecided", "I agree" and "I completely agree". Students were asked to select the option that best reflected their feelings and thoughts. The scale was responded by 150 prospective teachers studying at Turkish language and literature teaching departments of two majör city universities. In line with the five-Likert type scale utilized as data collection tool to interpret collected scores, the ranges were set by dividing range number by the number of options $(4 / 5=0,80)[12]$. Accordingly, in the detection of levels of scale items, score ranges were graded such: I completely disagree $1.00-1.80$, I disagree $1.81-2.60$, I am undecided $2.61-3.40$, I agree $3.41-4.20$, I completely agree 4.21 - 5.00). In data analysis SPSS program was harnessed; for the descriptive statistics constant variables mean scores \pm standard deviation and standard error were provided in a table format. For categorical variables data were summed as number and percentage. Kolmogrov Smirnov test was used to see if or not numeric variables performed a normal distribution. In the event that normal distribution was detected in the comparisons of two independent groups $T$-test was harnessed. For the presence of normal distribution among more than two independent groups One-Way ANOVA was employed. In all analyses significance level was stipulated as 0.05 .

\subsection{Results}

In this section it was investigated if prospective teachers' critical reading self-efficacy perception levels varied with respect to gender, enrolled department, grade levels, type of university entrance score, book types, frequency of reading books and availability of a library at home.

Table 2. ritical reading self-efficacy perception levels of prospective teachers

\begin{tabular}{cccccc}
\hline Dimensions & $\mathbf{N}$ & $\overline{\mathbf{X}}$ & $\mathbf{s s}$ & Min. & Maks \\
\hline Questioning & 150 & 4,41 & 40,81 & 30 & 50 \\
Deducing & 150 & 2,76 & 19,26 & 9 & 25 \\
Analysis & 150 & 3,60 & 28,15 & 18 & 35 \\
$\begin{array}{c}\text { Evaluation } \\
\text { Detecting }\end{array}$ & 150 & 3,46 & 24,43 & 16 & 30 \\
$\begin{array}{c}\text { similarities and } \\
\text { differences } \\
\text { Total }\end{array}$ & 150 & 2,76 & 20,44 & 11 & 25 \\
\hline
\end{tabular}

Table 2 demonstrates that prospective teachers answered questioning dimension of the scale for critical reading self-efficacy perceptions in $I$ completely agree level $(\overline{\mathrm{X}}=4,41)$, answered analysis $(\overline{\mathrm{X}}=3,60)$ and evaluation $(\overline{\mathrm{X}}=3,46)$ dimensions of the scale in I agree level, deducing $(\overline{\mathrm{X}}=2,76)$ and detecting similarities and differences $(\overline{\mathrm{X}}=2,76)$ subdimensions in I am undecided level

Table 3 posits that critical reading self-efficacy perceptions of prospective teachersvaried insignificantly with respect to enrolled university variable $(\mathrm{t}(148)=0,974$; $\mathrm{p}>.05)$.

Table 4 shows that prospective teachers' critical reading self-efficacy perceptions varied insignificantly with respect to gender variable $(t(60)=1,140 ; p>.05)$.

Table 3. t-Test results of prospective teachers' critical reading self-efficacy perception and enrolled university variable

\begin{tabular}{|c|c|c|c|c|c|c|c|c|}
\hline \multirow{2}{*}{ Enrolled University } & \multirow{2}{*}{$N$} & \multirow{2}{*}{$\overline{\mathbf{X}}$} & \multirow{2}{*}{ ss } & \multirow{2}{*}{ Sh } & \multicolumn{4}{|c|}{$t$ Test } \\
\hline & & & & & $t$ & $S d$ & & $p$ \\
\hline 1. University & 77 & 134,18 & 13,58 & 1,548 & \multirow{2}{*}{0,974} & \multirow{2}{*}{148} & \multirow{2}{*}{0} & \multirow{2}{*}{$0.332^{*}$} \\
\hline 2. University & 73 & 131,93 & 14,72 & 1,723 & & & & \\
\hline
\end{tabular}

Table 4. t-Test Results of prospective teachers' critical reading self-efficacy perceptions

\begin{tabular}{|c|c|c|c|c|c|c|c|}
\hline \multirow{2}{*}{ Gender } & \multirow{2}{*}{$N$} & \multirow{2}{*}{$\overline{\mathbf{X}}$} & \multirow{2}{*}{ ss } & \multirow{2}{*}{ Sh } & \multicolumn{3}{|c|}{$t$ Test } \\
\hline & & & & & $t$ & $S d$ & $p$ \\
\hline Female & 108 & 134,01 & 12,88 & 1,239 & \multirow{2}{*}{1,140} & \multirow{2}{*}{60} & \multirow{2}{*}{$0,0,259^{*}$} \\
\hline Male & 42 & 130,71 & 16,92 & 2,610 & & & \\
\hline
\end{tabular}


Table 5. ANOVA Results of prospective teachers' critical reading self-efficacy perceptions

\begin{tabular}{|c|c|c|c|c|c|c|c|c|c|}
\hline \multirow{2}{*}{ Grade } & \multirow{2}{*}{$N$} & \multirow{2}{*}{$\overline{\mathbf{X}}$} & \multirow{2}{*}{ ss } & \multicolumn{6}{|c|}{ ANOVA } \\
\hline & & & & & $K T$ & $S d$ & KO & $F$ & $p$ \\
\hline 1. grade & 43 & 134,37 & 14,26 & Inter-group & 543,200 & 3 & 181,067 & 0,903 & $0,441^{*}$ \\
\hline 2. grade & 37 & 131,76 & 14,05 & Intra-group & 29266,673 & 146 & 200,457 & & \\
\hline 3. grade & 32 & 135,63 & 14,90 & Total & 29809,873 & 149 & & & \\
\hline 4. grade & 38 & 130,79 & 13,50 & & & & & & \\
\hline Total & 150 & 133,09 & 14,14 & & & & & & \\
\hline
\end{tabular}

Table 5 presents that not a significant difference existed between prospective teachers' critical reading self-efficacy perceptions and mean scores of grade level variable $(\mathrm{F}(3,146)=0,903 ; p>.05)$.

Table 6. t-Test Results of prospective teachers' critical reading self-efficacy perceptions and age variable

\begin{tabular}{|c|c|c|c|c|c|c|c|}
\hline \multirow{2}{*}{ Age } & \multirow{2}{*}{$N$} & \multirow{2}{*}{$\overline{\mathbf{X}}$} & \multirow{2}{*}{ ss } & \multirow{2}{*}{ Sh } & \multicolumn{3}{|c|}{$t$ Test } \\
\hline & & & & & $t$ & $S d$ & $p$ \\
\hline $18-20$ age & 92 & 134,01 & 14,13 & 1,473 & \multirow{3}{*}{1,008} & \multirow{2}{*}{148} & \multirow{3}{*}{$0,315^{*}$} \\
\hline 21-23 age & 58 & 131,62 & 14,17 & 1,861 & & & \\
\hline Total & 150 & & & & & & \\
\hline
\end{tabular}

Table 6 presents that not a significant difference existed between prospective teachers' critical reading self-efficacy perceptions and age variable $(\mathrm{t}(148)=1,008 ; \mathrm{p}>.05)$.

Table 7. ANOVA Results of prospective teachers' critical reading self-efficacy perceptions and education level of mother variable

\begin{tabular}{|c|c|c|c|c|c|c|c|c|c|}
\hline \multirow[b]{2}{*}{$\begin{array}{c}\text { Education level } \\
\text { of mother }\end{array}$} & \multirow[b]{2}{*}{$N$} & \multirow{2}{*}{$\overline{\mathbf{x}}$} & \multirow[b]{2}{*}{ ss } & \multicolumn{6}{|c|}{ ANOVA } \\
\hline & & & & & $\boldsymbol{K} T$ & $S d$ & KO & $\boldsymbol{F}$ & $p$ \\
\hline Elementary education & 86 & 133,34 & 14,44 & Inter-group & 369,934 & 3 & 123,311 & 0,612 & 0,609 \\
\hline Secondary education & 21 & 130,67 & 12,77 & Intra-group & 29439,939 & 146 & 201,643 & & \\
\hline High-school & 29 & 135,34 & 13,97 & Total & 29809,873 & 149 & & & \\
\hline University & 14 & 130,50 & 15,18 & & & & & & \\
\hline Total & 150 & 133,09 & 14,14 & & & & & & \\
\hline
\end{tabular}

Table 7 demonstrates that not a significant difference existed between prospective teachers' critical reading self-efficacy perceptions and mean scores of education level of mother $(3,146)=0,612 ; p>.05)$.

Table 8. ANOVA Results of prospective teachers' critical reading self-efficacy perceptions and education level of father variable

\begin{tabular}{cccccccccc}
\hline & \multirow{2}{*}{$\begin{array}{c}\text { Education level } \\
\text { of father }\end{array}$} & $\boldsymbol{N}$ & $\overline{\mathbf{X}}$ & $\boldsymbol{s} \boldsymbol{c}$ & \multicolumn{3}{c}{ ANOVA } \\
\cline { 6 - 9 } & & & & & $\boldsymbol{K} \boldsymbol{T}$ & $\boldsymbol{S} \boldsymbol{d}$ & $\boldsymbol{K} \boldsymbol{O}$ & $\boldsymbol{F}$ & $\boldsymbol{p}$ \\
\hline Elementary education & 55 & 132,29 & 14,95 & Inter-group & 159,372 & 3 & 53,124 & 0,262 & $0,853^{*}$ \\
Secondary education & 26 & 132,42 & 11,11 & Intra-group & 29650,501 & 146 & 203,086 & \\
High-school & 48 & 134,58 & 15,15 & Total & 29809,873 & 149 & & \\
University & 21 & 132,57 & 13,60 & & & & & \\
Total & 150 & 133,09 & 14,14 & & & & & \\
\hline
\end{tabular}

Table 8 demonstrates that not a significant difference existed between prospective teachers' critical reading self-efficacy perceptions and education level of father variable $(\mathrm{F}(3,146)=0,262 ; p>.05)$.

Table 9. ANOVA Results of prospective teachers' critical reading self-efficacy perceptions and monthly income level of the family variable

\begin{tabular}{|c|c|c|c|c|c|c|c|c|c|}
\hline \multirow[b]{2}{*}{$\begin{array}{c}\text { Monthly income level of } \\
\text { the family }\end{array}$} & \multirow{2}{*}{$N$} & \multirow{2}{*}{$\overline{\mathbf{X}}$} & \multirow{2}{*}{ ss } & \multicolumn{6}{|c|}{ ANOVA } \\
\hline & & & & & $K T$ & $S d$ & KO & $\boldsymbol{F}$ & $p$ \\
\hline $1500-3000$ TL & 102 & 134,22 & 14,27 & Inter-group & 429,743 & 2 & 214,872 & 1,075 & $0,344^{*}$ \\
\hline $3000-4500$ TL & 40 & 131,00 & 13,86 & Intra-group & 29380,130 & 147 & 199,865 & & \\
\hline 4500 TL and above & 8 & 129,13 & 13,74 & Total & 29809,873 & 149 & & & \\
\hline Total & 150 & 133,09 & 14,14 & & & & & & \\
\hline
\end{tabular}


Table 9 displays that not a significant difference existed between prospective teachers' critical reading self-efficacy perceptions and mean scores of their family's monthly income level $(\mathrm{F}(2,147)=1,075 ; p>.05)$.

Table 10. ANOVA Results of prospective teachers' critical reading self-efficacy perceptions and frequency of book reading variable

\begin{tabular}{|c|c|c|c|c|c|c|c|c|c|}
\hline \multirow[b]{2}{*}{ Frequency of book reading } & \multirow{2}{*}{$N$} & \multirow{2}{*}{$\overline{\mathbf{X}}$} & \multirow{2}{*}{ ss } & \multicolumn{6}{|c|}{ ANOVA } \\
\hline & & & & & $K T$ & Sd & KO & $F$ & $p$ \\
\hline Everyday & 66 & 134,91 & 13,79 & Inter-group & 533,815 & 2 & 266,907 & 1,340 & $0,265^{*}$ \\
\hline Weekly & 49 & 132,76 & 13,82 & Intra-group & 29276,059 & 147 & 199,157 & & \\
\hline Once in a month or less & 35 & 130,11 & 15,11 & Total & 29809,873 & 149 & & & \\
\hline Total & 150 & 133,09 & 14,14 & & & & & & \\
\hline
\end{tabular}

Table 10 exhibits that not a significant difference existed between prospective teachers' critical reading self-efficacy perceptions and mean scores of their frequency of book reading $(\mathrm{F}(2,147)=1,340 ; p>.05)$.

Table 11. ANOVA Results of prospective teachers' critical reading self-efficacy perceptions and annual book reading variable

\begin{tabular}{|c|c|c|c|c|c|c|c|c|c|c|c|}
\hline \multirow{2}{*}{\multicolumn{2}{|c|}{ Annual book reading }} & \multirow{2}{*}{$N$} & \multirow{2}{*}{$\overline{\mathbf{X}}$} & \multirow{2}{*}{ ss } & \multicolumn{6}{|c|}{ ANOVA } & \multirow[b]{2}{*}{ Difference } \\
\hline & & & & & & $K T$ & $S d$ & KO & $f$ & $p$ & \\
\hline \multirow{4}{*}{ Questioning } & 1-5 books & 14 & 38,43 & 4,33 & Inter-group & 96,874 & 2 & 48,437 & 2,545 & $0,082^{*}$ & \\
\hline & 6-20 books & 83 & 41,27 & 4,20 & Intra-group & 2797,899 & 147 & 19,033 & & & \\
\hline & $\begin{array}{l}21 \text { and } \\
\text { above }\end{array}$ & 53 & 40,74 & 4,62 & Total & 2894,773 & 149 & & & & \\
\hline & Total & 150 & 40,81 & 4,41 & & & & & & & \\
\hline \multirow{4}{*}{ Deducing } & 1-5 books & 14 & 18,36 & 3,32 & Inter-group & 12,750 & 2 & 6,375 & 0,835 & $0,436^{*}$ & \\
\hline & 6-20 books & 83 & 19,33 & 2,39 & Intra-group & 1122,110 & 147 & 7,633 & & & \\
\hline & $\begin{array}{l}21 \text { and } \\
\text { above }\end{array}$ & 53 & 19,40 & 3,13 & Total & 1134,860 & 149 & & & & \\
\hline & Total & 150 & 19,26 & 2,76 & & & & & & & \\
\hline \multirow{4}{*}{ Analysis } & 1-5 books & 14 & 25,86 & 4,05 & Inter-group & 109,259 & 2 & 54,630 & 4,414 & $0,014^{*}$ & \multirow{4}{*}{$\begin{array}{l}6-20 \text { books }>1-5 \\
\text { books }\end{array}$} \\
\hline & 6-20 books & 83 & 28,75 & 3,56 & Intra-group & 1819,514 & 147 & 12,378 & & & \\
\hline & $\begin{array}{l}21 \text { and } \\
\text { above }\end{array}$ & 53 & 27,81 & 3,30 & Total & 1928,773 & 149 & & & & \\
\hline & Total & 150 & 28,15 & 3,60 & & & & & & & \\
\hline \multirow{4}{*}{ Evaluation } & 1-5 books & 14 & 21,79 & 3,72 & Inter-group & 114,673 & 2 & 57,337 & 5,059 & $0,008^{*}$ & \multirow{4}{*}{$\begin{array}{c}6-20 \text { books }>1-5 \\
\text { books } \\
21 \text { and above } \\
\text { books }>1-5 \text { books }\end{array}$} \\
\hline & 6-20 books & 83 & 24,88 & 3,35 & Intra-group & 1666,020 & 147 & 11,333 & & & \\
\hline & $\begin{array}{l}21 \text { and } \\
\text { above }\end{array}$ & 53 & 24,42 & 3,30 & Total & 1780,693 & 149 & & & & \\
\hline & Total & 150 & 24,43 & 3,46 & & & & & & & \\
\hline \multirow{4}{*}{$\begin{array}{c}\text { Detecting } \\
\text { similarities } \\
\text { and } \\
\text { differences }\end{array}$} & 1-5 books & 14 & 19,21 & 2,01 & Inter-group & 32,141 & 2 & 16,070 & 2,138 & $0,122^{*}$ & \\
\hline & 6-20 books & 83 & 20,77 & 2,79 & Intra-group & 1104,819 & 147 & 7,516 & & & \\
\hline & $\begin{array}{l}21 \text { and } \\
\text { above }\end{array}$ & 53 & 20,25 & 2,83 & Total & 1136,960 & 149 & & & & \\
\hline & Total & 150 & 20,44 & 2,76 & & & & & & & \\
\hline \multirow{4}{*}{$\begin{array}{l}\text { Critical } \\
\text { reading } \\
\text { self-efficacy } \\
\text { perception } \\
\text { scale }\end{array}$} & 1-5 books & 14 & 123,64 & 13,24 & Inter-group & 1560,992 & 2 & 780,496 & 4,062 & $0,019^{*}$ & \multirow{4}{*}{$\begin{array}{c}\text { 6-20 books }>1-5 \\
\text { books }\end{array}$} \\
\hline & 6-20 books & 83 & 134,99 & 13,46 & Intra-group & 28248,881 & 147 & 192,169 & & & \\
\hline & $\begin{array}{l}21 \text { and } \\
\text { above }\end{array}$ & 53 & 132,60 & 14,62 & Total & 29809,873 & 149 & & & & \\
\hline & Total & 150 & 133,09 & 14,14 & & & & & & & \\
\hline
\end{tabular}

Table 11 shows that with respect to prospective teachers' critical reading self-efficacy perceptions and annual book reading frequency, a statistically significant difference existed with the critical mean scores of analysis subdimension of reading self-efficacy perception scale $(p=$ $0,014 p<.05)$ Similarly a statistically significant difference was detected with respect to evaluation mean scores of the number of books read by prospective teachers $(p=0,008$ $p<.05)$. Also in terms of the number of books read by prospective teachers a statistically significant difference was detected between total mean scores of critical reading self-efficacy perception scale $(p=0,019 p<.05)$. In other relevant comparisons with respect to the number of books read by prospective teachers, not a statistically significant 
difference was detected between mean scores of subdimensions such as questioning, deducing and detecting similarities and differences.

Table 12. Results of prospective teachers' critical reading self-efficacy perceptions and availability of a library in residential location variable

\begin{tabular}{|c|c|c|c|c|c|c|c|c|}
\hline \multirow[b]{2}{*}{$\begin{array}{l}\text { Availability } \\
\text { of a library }\end{array}$} & & \multirow[b]{2}{*}{$N$} & \multirow{2}{*}{$\overline{\mathbf{X}}$} & \multirow[b]{2}{*}{ ss } & \multirow[b]{2}{*}{ Sh } & \multicolumn{3}{|c|}{$t$ Test } \\
\hline & & & & & & $t$ & $S d$ & $p$ \\
\hline $\begin{array}{l}\text { Critical } \\
\text { reading }\end{array}$ & Yes & 135 & 133,74 & 13,97 & 1,202 & & & \\
\hline $\begin{array}{c}\text { self-efficacy } \\
\text { perceptio } \\
\text { n scale }\end{array}$ & No & 15 & 127,20 & 14,83 & 3,829 & 1,710 & 148 & $0,089^{*}$ \\
\hline
\end{tabular}

Table 12 illustrates that a statistically significant difference existed between prospective teachers' critical reading self-efficacy perception scale and availability of a library in their residential location $(\mathrm{t}(148)=1,710 ; p<.05)$. This difference exhibited that students having a library in their residential location obtained higher mean scores from the deducing subdimension when compared to students with no library available.

\section{Discussion and Conclusions}

In this study it was detected that prospective Turkish language and literature teachers responded to the questioning dimension of critical reading self-efficacy perceptions scale in I completely agree level; analysis and evaluation dimensions in I agree level; responded to deducing and detecting similarities and differences subdimensions in I partially agree (undecided) level. Obtained findings of this study revealed that prospective teachers' critical reading self-efficacy perceptions are in a high level. This high ratio may be connected with the fact that university students constituting the research population belong to the top two universities that select for their department the highest achievers of university entrance exam in Turkey.

Accordingly it can be claimed that prospective Turkish language and literature teachers prioritize, though not in high levels, identifying differences and similarities and reaching deductions. It is important that language and literature instructors are raised as teachers particularly keen on reading and who are ardent readers knowing how to treat the text on which s/he can conduct questioning, analysis and evaluation processes. Thus we can argue that such teachers can contemplate on a text read, question and examine the subject matter, investigate its rights and wrongs and conduct analyses and evaluations.

It can be seen in relevant literature that Aybek and Aslan [4] in their study "Analysis of Prospective Teachers' Critical reading Self-efficacy Perceptions with respect to Different Variables" manifested that prospective teachers' critical reading self-efficacy perceptions pointed to I agree level; this finding was interpreted in the way that prospective teachers' critical reading self-efficacy perceptions are in a high level. In the study of Aşılıoglu and Yaman [3] on "Self-efficacy Perceptions of Prospective Teachers towards Critical Reading", perception levels of prospective teachers on critical reading were mostly in (I agree) level. In the study of Karasakaloğlu, Saracaloğlu and Özelçi [14] "Prospective Classroom Teachers' Perceptions on their Critical Reading Self-Efficacy" it was detected that self-efficacy perceptions of prospective teachers on critical reading were low. In particular, the answers provided to open-ended questions revealed that prospective teachers lacked satisfactory knowledge and skills on the topics of critical thinking and critical reading; it was then argued that prospective teachers conceptualized critical reading as the attempts to detect positive and negative aspects. In the analysis of Ünal and Sever [29] on "Self-efficacy Perceptions of Prospective Turkish Teachers towards Critical Reading" it was reported that students maintained high critical levels of self-efficacy perception towards reading.

It was demonstrated in present study that prospective Turkish language and literature teachers' critical reading self-efficacy perceptions varied insignificantly with respect to variables viz. Enrolled university, gender, grade level, age, education level of parents, family income level and frequency of book reading. It was detected that in relevant literature a number of studies identified parallel results or truly-opposite results. Likewise in the study of Aybek and Aslan [4] it was revealed that gender created no effect on critical reading self-efficacy perception; however unlike other analyses in the research of Aş1lığlu and Yaman [3] a difference in favor of female students was detected with respect to gender factor impinging upon prospective teachers' critical reading self-efficacy perceptions. In the study of Murathan, Yetiş, Uğurlu and Murathan [20] on "Analyzing Self-efficacy Perceptions of Physical Education Teachers towards Critical Reading Skill" it was concluded that with respect to gender factor prospective teachers' critical reading self-efficacy perceptions differed in favor of male participants.

The reason for detecting not any significant difference in the critical reading self-efficacy levels of prospective Turkish language and literature teachers with respect to enrolled university is, we believe, both universities select the top-score achieving students in university entrance exam. With respect to the variable of grade level it was seen that 3rd grade students maintained relatively higher, though insignificantly, critical reading self-efficacy perceptions than the other graders. This finding may be interpreted such that knowledge background prospective teachers stored till 3rd grade played vital role. The reason why this ratio was lower in 4th grade than third grade could be the anxiety of senior students for the assignment process as public school teachers and to find a career in teaching. In parallel with our finding in their analysis Ünal and Sever 
[29] detected that there was an identifiable difference in the critical reading self-efficacy perceptions of 3rd grade prospective teachers. Similarly in the same research not a significant difference was detected with respect to gender variable. In our study either not a significant difference was detected in relation to reading frequency and critical reading self-efficacy but a significant difference was measured between annual reading ratio and critical reading self-efficacy. In relation to that finding, it can be claimed that constant engagement with reading activity may fail at providing critical reading insights since this finding also calls for some a-priori knowledge on the type of text being read. In relevant literature studies conducted by Aşılıoğlu and Yaman [3] and Ünal and Sever [29] to search the relation between book reading frequency of prospective teachers and their critical reading self-efficacy perceptions, a higher score in favor of critical reading self-efficacy perceptions among constant book readers was measured compared to other groups; however it should also be noted that the difference was not in a high ratio. It can thus reasonably be argued that in our research annual book reading ratio offered a more precise idea. Indeed it has been detected that students whose annual book reading ratio ranged between 6 to 20 possessed higher critical reading self-efficacy compared to students reading 1-5 books in a year. In parallel with this research finding, in the study of Karasakaloğlu, Saracaloğlu and Özelçi [14], it was determined that almost half $(48 \%)$ of 175 prospective classroom teachers read 6-20 books within a year. In our study it was identified that among 150 prospective Turkish language and literature teachers 83 teachers $(55 \%)$ read 620 books in one year. In the study of Aybek and Aslan [4] it was detected that a significant difference existed between those reading a book weekly and those reading one book quarterly with respect to critical reading perceptions.

In our research a statistically significant difference was observed in relation to Turkish language and literature prospective teachers' critical reading self-efficacy perception from the mean scores of deducing subdimension and availability of a library in the residential location subdimension. In the research of Aybek and Aslan [4] it was detected that a significant different existed in favor of critical reading perceptions between availability of a library at home and prospective teachers' critical reading self-efficacy perceptions.

Based on the findings of this study below-listed suggestions can be proposed:

1. This research could be administered among different sampling groups.

2. So as to fulfill the item "Competent to improve the critical and creative thinking, decisionmaking and problem-solving skills of students" integrated to course-specific competencies of Turkish language and literature teachers, it is suggested that courses such as critical thinking in education, creative education, contemporary criticism education, creative project development should be integrated to Turkish Language and Literature Teaching Curriculum.

3. Action research, experimental studies and various research methods could be applied to the end of developing prospective teachers' critical reading self-efficacy levels.

4. The relationship between prospective teachers' critical reading self-efficacy perceptions and a range of other variables could be analyzed.

5. Starting with critical thinking first, sample educational materials such as course plans and activities could be devised to hone the critical reading and listening skills of all learner levels.

\section{Acknowledgements}

We are very grateful to experts for their appropriate and constructive suggestions to improve this template.

\section{REFERENCES}

[1] Akyol, H. (2011). Türkçe öğretim yöntemleri. Ankara: Pegem Akademi Yayıncilik.

[2] Akyol, A. (2011). 2005 ilköğretim ikinci kademe Türkçe dersi ögrretim programında eleștirel okuma. Yayınlanmamış yüksek lisans tezi. Afyonkarahisar: Afyon Kocatepe üniversitesi sosyal bilimler enstitüsü.

[3] Aş1lığlu, B. \& Yaman F. (2017). Öğretmen adaylarının eleştirel okumaya yönelik öz yeterlik algıları. Elektronik Ĕ̈itim Bilimleri Dergisi, 6 (12), 171-179.

[4] Aybek, B. \& Aslan, S. (2015). Öğretmen adaylarının eleştirel okuma öz yeterlik algılarının çeşitli değişkenler açısından incelenmesi. Uluslararası Türkçe Edebiyat Kültür Eğitim Dergisi, 4 (4), 1672-1683.

[5] Bandura, A. (1986). Social Foundations of Thought and Action: A Social Cognitive Theory. Englewood Cliffs, NJ: Prentice-Hall.

[6] Çifçi, M. (2006). Eleştirel okuma. Belleten, s. 55-80.

[7] Erden, M. (1998). Eğitimde Program Değerlendirme. Ankara: An1 Yayınc1lık.

[8] Eskimen A. D. (2015). Ders Kitapları. Çetin, İ. (Editör) Dil ve Edebiyat Ögretim Yöntemleri. (s.433-467). Ankara: Nobel Yayıncilık.

[9] Günay, D. (2001). Metin bilgisi. İstanbul: Multilingual Yayınlar1.

[10] Güncel Türkçe Sözlük. http://www.tdk.gov.tr (Erișim Tarihi 19.02.2018).

[11] İpşiroğlu, Z. (1998) Eleştirinin Eleştirisi. İstanbul: MitosBOYUT Yayınları.

[12] Kaptan, S. (1998). Bilimsel Araştırma ve İstatistik Teknikleri. Ankara: Tekışık Web Ofset Tesisleri. 
[13] Karadeniz, A. (2014). Eleştirel okuma özyeterlilik algıs1 ölçeğinin geçerlilik ve güvenirlik çalışması. Bartın Üniversitesi Eğitim Fakültesi Dergisi, 3 (1), 113-140.

[14] Karasakaloğlu, N., Saracaloğlu A. S, \& Özelçi, S. (2012). Sınıf öğretmeni adaylarının eleştirel okuma öz yeterliklerine ilişkin algıları. Mustafa Kemal Üniversitesi Sosyal Bilimler Enstitüsü Dergisi, 9 (19), 405 - 422.

[15] Kurbanoğlu, S. S. (2004). Öz-yeterlik inanc1 ve bilgi profesyonelleri için önemi. Bilgi Dünyası, 5 (2), 137-152.

[16] Kurt, A. A. \& Kürüm, D. (2010). Medya okuryazarlığ1 ve eleştirel düşünme arasındaki ilişki: Kavramsal bir bakış. Mehmet Akif Ersoy Üniversitesi Sosyal Bilimler Enstitüsü Dergisi, 2 (2), 20-34.

[17] Küçükoğlu, H. (2008). Ingilizce öğretmen adaylarının eleştirel okumaya yönelik öz yeterlik algıları. Yayınlanmamış yüksek lisans tezi. Diyarbakır: Dicle üniversitesi sosyal bilimler enstitüsü.

[18] Millî Eğitim Bakanlığı. Türk Dili ve Edebiyatı Öğretmeni Özel Alan Yeterlikleri (2011). Öğretmen Yetiştirme ve Eğitimi Genel Müdürlüğü. Öğretmen Yeterlikleri ve Okul Temelli Mesleki Gelişim ,http://otmg.meb.gov.tr/yeterlikdo s (Erişim Tarihi 20.03.2018).

[19] Millî Eğitim Bakanlığg (2018). Ortaöğretim Türk dili ve edebiyatı dersi $(9,10,11$ ve 12 . sinıflar) öğretim programı. $\mathrm{http}: / /$ mufredat.meb.gov.tr/ProgramDetay.aspx?PID=353 (Erişim Tarihi 30.02.2018).

[20] Murathan, T., Yetiş, Ü., Uğurlu, F. M. \& Murathan, F.
(2017). Beden eğitimi öğretmenlerinin eleștirel okuma becerisine ilişkin öz yeterlik algısının incelenmesi, Turkish Studies, 12 (4), 393-404.

[21] Naisbitt, J. (1982). Megatrends: Ten New Directions Transforming Our Lives Hardcover. New York: Warner Books.

[22] Odabaș ,H., Odabaş, Z. Y. \& Polat, C. (2008). Üniversite öğrencilerinin okuma alışkanlığı: Ankara üniversitesi örneği, Bilgi Dünyası, 9 (2), 431-465.

[23] Özbay, M. (2007). Türkçe Özel Öğretim Yöntemleri II Ankara: Öncü Basımevi.

[24] Özdemir, E. (1987). Türkçe Öğretimi Kılavuzu. İstanbul: İnk1lap Kitapevi.

[25] Özdemir, E. (2007). Eleştirel Okuma. Ankara: Bilgi Yayınevi.

[26] Özensoy, A. U. (2011). Eleştirel okumaya göre düzenlenmiş sosyal bilgiler dersinin eleștirel düşünme becerisine etkisi. Mersin Üniversitesi Ĕ̈itim Fakültesi Dergisi, 7 (2), 13-25.

[27] Senemoğlu, N. (2011). Gelişim, Öğrenme ve Öğretim Kavramdan Uygulamaya. Ankara: Pegem Akademi.

[28] Tanpınar, A. H. (2013). Edebiyat Dersleri. Uçman, A. (Hazırlayan). İstanbul: Dergâh Yayınları.

[29] Ünal F. \& Sever, A, (2013). Türkçe öğretmeni adaylarının eleştirel okumaya yönelik öz yeterlik algıları. Dil ve edebiyat eğitimi dergisi, 2 (6), 33-42. 